\title{
The solid phase synthesis of tertiary hydroxyesters from symmetrical diacid chlorides using organomanganese reagents ${ }^{1,2}$
}

\author{
Clifford C. Leznoff and Varda Yedidia \\ Department of Chemistry, York University, Downsuiew, Ont., Canada M3.J IP3
}

\begin{abstract}
Clifford C. Leznoff and Varda Yedidia. Can. J. Chem. 58, 287 (1980).
A $1 \%$ crosslinked divinylbenzene-styrene copolymer, incorporating benzyl alcohol groups, was used to monoblock the symmetrical diacid chlorides, $\mathrm{ClOC}\left(\mathrm{CH}_{2}\right)_{n} \mathrm{COCl}$ (where $n=4$ and 8 ). Further reaction of the polymer-bound monoester monoacid chloride with phenylmanganese iodide or butylmanganese iodide gave their respective polymer-bound tertiary hydroxyesters. Subsequent base cleavage and esterification yielded methyl 6-hydroxy-6,6-diphenylhexanoate, methyl 10-hydroxy-10,10-diphenyldecanoate, methyl 6-butyl-6-hydroxydecanoate, and methyl 10-butyl-10-hydroxy tetradecanoate and some recovered dimethyl alkanoates. The reactions of some polymer-bound monoester monoacid chlorides with phenylcadmium chloride were also studied.
\end{abstract}

\begin{abstract}
Clifford C. Leznoff et Varda Yedidia. Can. J. Chem. 58, 287 (1980).
On a utilisé un copolymère styrène-divinylbenzène reticuléà $1 \%$ et contenant des groupes alcool benzylique pour bloquerune des fonctions des dichlorures de diacides symétriques $\mathrm{ClOC}\left(\mathrm{CH}_{2}\right)_{n} \mathrm{COCl}$ (où $n=4 \mathrm{et} 8$ ). La réaction de l'ester ainsi obtenu avec l'iodure de phénylmanganèse ou l'iodure de butylmanganèse conduit à leurs hydroxy-esters tertiaires respectifs fixés sur la résine. Le clivage subséquent par une base suivi d'une estérification conduit aux composés: hydroxy- 6 diphényl-6,6 hexanoate de méthyle, hydroxy-10 diphényl-10,10 décanoate de méthyle, butyl-6 hydroxy-6 décanoate de méthyle et le butyl-10 hydroxy-10 tétradécanoate de méthyle et également à la récupération de quelques alkanoates de méthyle. On a également étudié les rêactions de quelques
\end{abstract} monochlorures d'acides fixés sur la résine par une liaison ester avec le chlorure de phénylcadmium.

[Traduit par le journal]

\section{Introduction}

Tertiary hydroxyesters have been prepared before but in low yields and in multiple step reactions. Thus diethyl succinate reacted with benzophenone in a Stobbe condensation to give, after several further reactions, 4,4-diphenyl- $\gamma$-butyrolactone (5) useful against pathogenic viruses (6). Alternatively, reaction of succinic anhydride with phenylmagnesium bromide gave a mixture of products, one of which was 4-hydroxy-4,4-diphenylbutanoic acid (7).

It has been previously shown in our laboratory that insoluble polymer supports (8) can be used to monoprotect symmetrical diacid chlorides as the monoester monoacid chloride and several monoamide monoesters and primary hydroxyesters were prepared via solid phases $(9,10)$. In this paper we describe a general synthesis of hydroxyesters, disubstituted at the hydroxy position, from polymerbound monoester monoacid chlorides.

\section{Results and Discussion}

The previously described (10) polymer-bound monoester monoacid chlorides (1) and (2), derived from adipyl and sebacyl chloride respectively,

'The use of polymer supports in organic synthesis. Part XXI. For parts XX, XIX, XVIII, and XVII, see refs. 1-4 respectively

2Presented, in part, at the 61st Annual Conference of the Chemical Institute of Canada, Winnipeg, Man., Canada, June 1978. were treated in benzene at $0^{\circ} \mathrm{C}$ with an excess of phenylmanganese iodide $(3)(11,12)$ or butylmanganese iodide (4) $(11,12)$ in ether to give the polymer-bound tertiary hydroxyesters (5-8) respectively as shown in Scheme 1.

The infrared spectra of 5-8 exhibited strong absorptions at $1740 \mathrm{~cm}^{-1}$ and broad absorptions between $3200-3600 \mathrm{~cm}^{-1}$ indicative of ester and alcohol groups respectively. Cleavage of 5-8 with $\mathrm{K}_{2} \mathrm{CO}_{3}$ in methanol followed by esterification with diazomethane as previously described (10) yielded methyl 6,6-diphenyl-6-hydroxyhexanoate (9) (13), methyl 10,10-diphenyl-10-hydroxydecanoate (10), methyl 6-butyl-6-hydroxydecanoate (11), and methyl 10-butyl-10-hydroxytetradecanoate (12) respectively in good yield (Table 1). In addition, some dimethyl adipate (13) and dimethyl sebacate (14) were recovered from the reactions involving 1 and 2 respectively and separated from the products by preparative thin layer chromatography (tlc). The recovery of $\mathbf{1 3}$ and 14 is likely due to incomplete reaction of 1 and 2 with the organomanganese iodide reagents since our previous work (10) showed that most of the symmetrical diacid chlorides were monobound to the polymer although some double-binding of the diacid chlorides cannot be completely dismissed at this time $(8,14)$. The polymer itself was recovered as polymerbound benzyl alcohol (15) and is recyclable by simple standard washing procedures as the organo- 


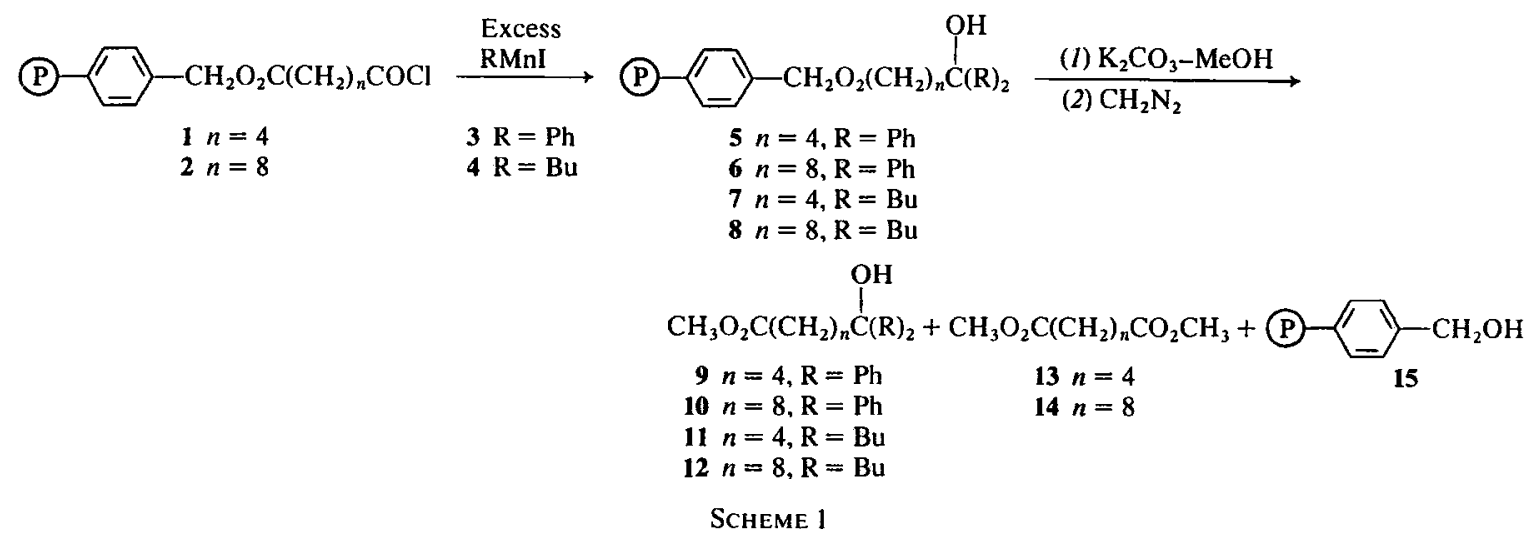

TABLE 1. Yields of tertiary hydroxyesters 9-12 recovered from cleavage of polymers 5-8

\begin{tabular}{|c|c|c|c|c|c|c|c|c|}
\hline \multirow{2}{*}{$\begin{array}{l}\text { Tertiary } \\
\text { hydroxy- } \\
\text { ester }\end{array}$} & \multicolumn{2}{|c|}{$\begin{array}{c}\text { Loading capacity of } 15 \\
\text { quantity of } 13 \text { and } 14 \\
\text { per gram of } 15^{\alpha}\end{array}$} & \multicolumn{2}{|c|}{$\begin{array}{l}\text { Recovered products } \\
\text { quantity of } 9-12 \\
\text { per gram of } 15^{b}\end{array}$} & \multicolumn{2}{|c|}{$\begin{array}{l}\text { Recovered diester } \\
\text { quantity of } 13 \text { and } \\
14 \text { per gram of } 15^{c}\end{array}$} & \multirow{2}{*}{$\begin{array}{l}\text { Overall } \\
\text { iyield } \\
(\%)\end{array}$} & \multirow{2}{*}{$\begin{array}{c}\text { Conversion } \\
(\%)\end{array}$} \\
\hline & $(\mathrm{mg} / \mathrm{g})$ & $(\mathrm{mmol} / \mathrm{g})$ & $(\mathrm{mg} / \mathrm{g})$ & $(\mathrm{mmol} / \mathrm{g})$ & $(\mathrm{mg} / \mathrm{g})$ & $(\mathrm{mmol} / \mathrm{g})$ & & \\
\hline 9 & 72.0 & 0.41 & 104 & 0.35 & 7.0 & 0.04 & 85 & 94 \\
\hline 10 & 126.5 & 0.55 & 69.7 & 0.27 & 21.7 & 0.09 & 49 & 59 \\
\hline 11 & 73.1 & 0.42 & 69.3 & 0.27 & 18.3 & 0.105 & 64 & 84 \\
\hline 12 & 121.9 & 0.53 & 77.3 & 0.26 & 27.3 & 0.12 & 49 & 63 \\
\hline
\end{tabular}

Obtained from cleavage of polymer-bound corresponding monoester monoacids.

cYields of dimethylesters recovered from the reaction mixture after cleavage of polymer-bound tertiary hydrox yesters.

Yield of tertiary hydrox yesters compared to acid chloride initially bound to polymer.

manganese and organocadmium reagents leave no insoluble impurities. The loading capacities of 1 and 2 were determined as previously described (10) and are given in Table 1. The spectroscopic and physical data of 9-12 are entirely consistent with the assigned structures and are given in the Experimental.

It should be noted that organomanganese iodide reagents were initially introduced as reacting selectively with acid chlorides to give ketones (11). It was later shown, however, that organomanganese iodide reagents do react with ketones albeit more slowly, but not at all with esters (12). Thus the syntheses of 5-8 utilized this selectivity for the first time so that the free acid chloride in the presence of an ester can react with two equivalents of 3 or 4 to give exclusively the tertiary hydroxyesters. The previously reported (13) synthesis of 5 , for example, was accomplished in 5 steps in $\sim 20 \%$ overall yield from dimethyl adipate, compared to our 4step synthesis in $85 \%$ yield (Table 1 ).

The possibility of preparing tertiary hydroxyesters with different substituents on the tertiary hydroxy carbon atom was then explored. Treatment of a polymer-bound monoester monoacid chloride (16) derived from azeloyl chloride with phenyl cadmium chloride (15) in benzene at $0^{\circ} \mathrm{C}$ yielded the polymer-bound keto esters 17 and 18 as shown in Scheme 2.

Cleavage and esterification of 17 and 18 as above gave methyl 10-oxo-10-phenyldecanoate (19) and methyl 9-oxo-9-phenylnonanoate (20) respectively. Unfortunately, 19 was contaminated with 13 , and 20 with dimethyl azelate (21), and in these cases the keto esters could not be readily separated from their respective diester precursors even by preparative tlc. The yields of 19 and 20 in the mixture obtained from the phenyl cadmium chloride reaction were estimated from the nmr spectrum of the fraction containing 19 and 13 , and 20 and 21 , respectively. Although a few attempts were made to synthesize unsymmetrical tertiary hydroxyesters by reaction of 18 with butylmanganese iodide, inseparable mixtures of products were obtained.

\section{Conclusions}

Hydroxyesters, symmetrically disubstituted at the carbon atom bearing the alcohol group, have been selectively prepared in good yield in a single key step from polymer-bound monoester monoacid chlorides. We have confirmed that the recently 


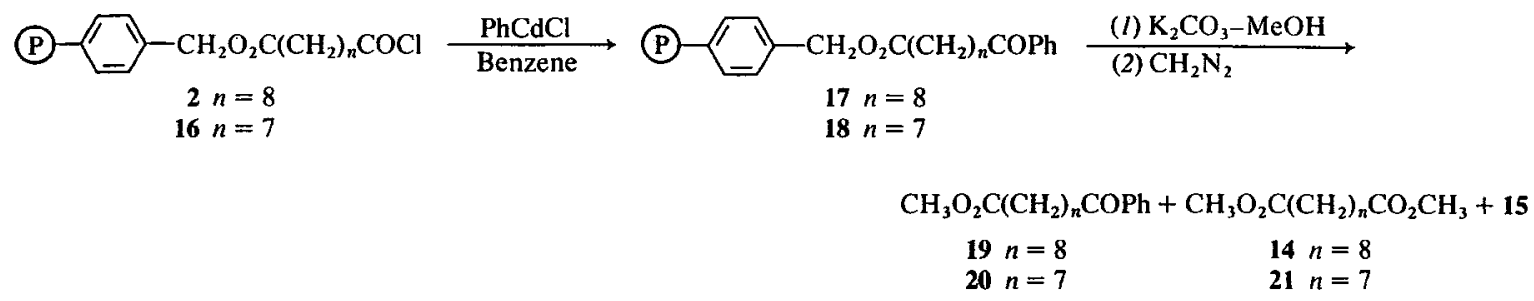

SCHEME 2

described organomanganese iodide and organocadmium chloride reagents are easy to prepare, easy to use, give no sludges during or on completion of the reaction and should find wide use in synthetic organic chemistry. Since these reagents leave no residues as can occur with some organocopper reagents (16), they are particularly useful in conjunction with organic syntheses on solid phases.

\section{Experimental}

A chloromethylated 1\% divinylbenzene (DVB)-styrene copolymer, containing 1.09 mequiv. $\mathrm{Cl} / \mathrm{g}$ of resin, obtained from Sigma Chemical Company was used as the starting resin in all resin transformations. Filtration was done under vacuum using sintered glass Büchner funnels. Suspensions and solutions were stirred using magnetic stirrers. Matheson high purity argon was used to maintain inert atmosphere conditions. Infrared (ir) spectra were recorded on a Pye Unicam SP1000 infrared spectrophotometer using $\mathrm{KBr}$ discs for solids or as neat films bet ween $\mathrm{NaCl}$ discs. Nuclear magnetic resonance $(\mathrm{nmr})$ spectra were recorded on a Varian LM 360 spectrometer using deuterochloroform as solvent and tetramethylsilane as the internal standard. The positions of the signals are reported in $\delta$ units. (The splittings of the signals are described as singlets (s), doublets (d), triplets $(t)$, quartets (q), or multiplets (m).) Mass spectra (ms) were recorded at $70 \mathrm{eV}$ on a Hitachi-Perkin-Elmer RMU $6 \mathrm{E}$ mass spectrometer. The number in parentheses after the indicated ion shows the percentage of the base peak represented by that ion. Melting points (mp) were determined using a Kofler hot stage melting point apparatus and are uncorrected. Thinlayer chromatography (tlc) was performed using silica gel $\mathrm{G}$ as the adsorbent. Microanalyses were done by G. Gygli of Toronto. Spectral and analytical data are given for all new compounds and for known compounds where data are unreported.

Preparation of Polymer-bound Acid Chlorides 1, 2, and 16

A suspension of a $1 \%$ crosslinked divinylbenzene (DVB)styrene copolymer containing benzyl alcohol groups (15) (17) in THF was treated with the corresponding diacid chlorides by a method previously described (10) to give the polymer-bound acid chlorides 1,2 , and 16 .

The quantities of the corresponding diacid chlorides bound to polymer 1 were determined by hydrolysis of 1,2 , or 16 as before (10) to give their respective polymer-bound monoester monoacids. They were then cleaved with $\mathrm{K}_{2} \mathrm{CO}_{3}$ in methanol and esterified to yield the respective dimethylesters (10) from which the loading capacities of 1,2 , and 16 were calculated and given in Table 1.

Preparation of Polymer-bound Tertiary Hydroxyesters 5-8 To a suspension of $2 \mathrm{~g}$ of polymer 1 or 2 in $50 \mathrm{~mL}$ of dry benzene at $0^{\circ} \mathrm{C}$ under an argon atmosphere was added $15 \mathrm{mmol}$ of phenylmanganese iodide (3) or butylmanganese iodide (4) in $10 \mathrm{~mL}$ at $\mathrm{Et}_{2} \mathrm{O}$ (11). After the addition the reaction mixture was allowed to warm to room temperature and was stirred for $12 \mathbf{h}$. The excess organomanganese iodide was decomposed with $50 \mathrm{~mL}$ of a saturated solution of ammonium chloride. The polymer was filtered and washed with water (twice), methanol (twice), THF (twice), and $\mathrm{Et}_{2} \mathrm{O}$ ( 3 times), and air dried to give the polymer-bound tertiary hydroxyesters $5-8$; ir $(\mathrm{KBr})$ : $3200-3600$ (broad, $\mathrm{O}-\mathrm{H})$ and $1740\left(\mathrm{CO}_{2} \mathrm{R}\right) \mathrm{cm}^{-1}$.

Preparation of the Tertiary Hydroxyesters 9-12

A suspension of $2 \mathrm{~g}$ of polymer 5 was cleaved with $\mathrm{K}_{2} \mathrm{CO}_{3}$ in methanol (10) and the product was esterified with $\mathrm{CH}_{2} \mathrm{~N}_{2}$. The reaction mixture $(250 \mathrm{mg}$ ) was purified by preparative tlc using hexane-acetone (4:1) to give $208 \mathrm{mg}$ of methyl 6,6-diphenyl-6hydroxyhexanoate (9) as a solid. The solid was recrystallized from hexane to give pure $9, \mathrm{mp} 81-82^{\circ} \mathrm{C}$ (lit (13) $\mathrm{mp} 82-83^{\circ} \mathrm{C}$ ); ir $(\mathrm{KBr}): 3450(\mathrm{OH}), 1715\left(\mathrm{CO}_{2} \mathrm{Me}\right)$, and 1600 (phenyl) $\mathrm{cm}^{-1} ; \mathrm{nmr}$ $\delta: 7.1-7.6(\mathrm{~m}, 10$, aromatic $\mathrm{H}), 3.55\left(\mathrm{~s}, 3, \mathrm{CH}_{3} \mathrm{O}\right), 2.2-2.5(\mathrm{~m}, 4$, $\mathrm{OH}$

$\mathrm{CH}_{2} \mathrm{CO}$ and $\left.\mathrm{CH}_{2} \mathrm{CPh}_{2}\right), 2.17(\mathrm{~s}, 1, \mathrm{OH})$, and $1.1-1.9\left(\mathrm{~m}, 4, \mathrm{CH}_{2}\right)$; $\mathrm{ms} m / e: 280(40)\left(\mathrm{M}^{+}-\mathrm{H}_{2} \mathrm{O}\right), 206(100), 115(68), 91(83)$.

Similarly 6 gave methyl 10,10-diphenyl-10-hydroxydecanoate (10), $\mathrm{mp} 47-48^{\circ} \mathrm{C}$; ir $(\mathrm{KBr}): 3500(\mathrm{O}-\mathrm{H}), 1710\left(\mathrm{CO}_{2} \mathrm{R}\right)$, and $\mathrm{I} 600$ (phenyl) $\mathrm{cm}^{-1} ; \mathrm{nmr} 8: 7.2-7.6(\mathrm{~m}, 10$, aromatic $H), 3.7(\mathrm{~s}, 3$, $\left.\mathrm{OCH}_{3}\right), 2.1-2.5\left(\mathrm{~m}, 4, \mathrm{CH}_{2} \mathrm{C}=\mathrm{O}\right.$ and $\left.\mathrm{CH}_{2} \mathrm{COPh}_{2}\right), 2.14(\mathrm{~s}, 1$ $\mathrm{O}-\mathrm{H}), 1.1-1.6\left(\mathrm{~m}, 12, \mathrm{CH}_{2}\right)$; ms m/e: $336(40)\left(\mathrm{M}^{+}-\mathrm{H}_{2} \mathrm{O}\right), 193$ (100), 115 (88), 91 (55). Anal. calcd. for $\mathrm{C}_{23} \mathrm{H}_{30} \mathrm{O}_{3}: \mathrm{C} 77.93, \mathrm{H}$ 8.53; found: C 77.89, H 8.67.

Similarly 7 yielded methyl 6-butyl-6-hydroxydecanoate (11) as an oil after purification on preparative tlc using methanol-chloroform (1:99) as eluant; ir (neat): $3300-3600$ (b, $\mathrm{OH})$, and $1740\left(\mathrm{CO}_{2} \mathrm{CH}_{3}\right) \mathrm{cm}^{-1} ; \mathrm{nmr} \delta: 3.65\left(\mathrm{~s}, 3, \mathrm{OCH}_{3}\right), 2.3(\mathrm{t}, J$ $\left.=6 \mathrm{~Hz}, 2, \mathrm{CH}_{2} \mathrm{C}=0\right), 1.6(\mathrm{~s}, 1, \mathrm{O}-\mathrm{H}), 1.1-1.5\left(\mathrm{~m}, 19, \mathrm{CH}_{2}\right)$, $0.9\left(\mathrm{t}, J=6 \mathrm{~Hz}, \mathrm{CH}_{3}\right)$; ms mle: $230(6)\left(\mathrm{M}^{+}-\mathrm{H}_{2} \mathrm{O}\right), 85(100), 55$

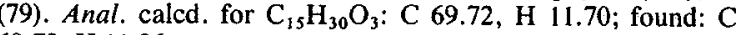
69.73, H 11.86.

Similarly 8 gave methyl 10-butyl-10-hydroxytetradecanoate (12) as an oil; ir (neat): $3350-3550(\mathrm{O}-\mathrm{H})$, and $1730-1750$ $\left(\mathrm{CO}_{2} \mathrm{R}\right) \mathrm{cm}^{-1} ; \mathrm{nmr} \delta: 3.67\left(\mathrm{~s}, 3, \mathrm{O}-\mathrm{C} H_{3}\right), 2.32(\mathrm{t}, J=7 \mathrm{~Hz}$, 2, $\left.\mathrm{CH}_{2} \mathrm{C}=0\right), 1.3-1.4\left(\mathrm{~m}, 27,-\mathrm{CH}_{2}-\right.$ and $\left.\mathrm{OH}\right), 0.9(\mathrm{t}, \mathrm{J}=$ $\left.6 \mathrm{~Hz}, \mathrm{CH}_{3}\right)$; ms m/e: 298 (9) $\left(\mathrm{M}^{+}-\mathrm{H}_{2} \mathrm{O}\right), 55(100), 41(86)$. Anal. calcd. for $\mathrm{C}_{19} \mathrm{H}_{38} \mathrm{O}_{3}: \mathrm{C} 72.55, \mathrm{H} \mathrm{12.18}$; found: $\mathrm{C} 72.14, \mathrm{H} 12.19$.

In the separation of the products the corresponding dimethyl esters were detected and separated from the monoester monotertiary alcohols by preparative tlc. The quantities of recovered dimethyl esters and the yields of monoester monotertiary alcohols are reported in Table 1.

\section{Preparation of Polymer-bound Ketoesters 17 and 18}

To a suspension of $2 \mathrm{~g}$ of polymer 2 or 16 in $40 \mathrm{~mL}$ of dry benzene at $0^{\circ} \mathrm{C}$ under an argon atmosphere was added $7 \mathrm{mmol}$ of phenyl cadmium chloride (15) in $15 \mathrm{~mL}$ of dry benzene. The 
reaction mixture was allowed to warm to room temperature and was stirred for $24 \mathrm{~h}$, after which $50 \mathrm{~mL}$ of $2 \%$ sulfuric acid was added and stirred for $10 \mathrm{~min}$. The polymer was filtered and washed with benzene (twice), water (twice), methanol (twice), benzene (once), and ether ( 3 times), and air dried to give the polymer-bound ketoesters 17 or 18 ; ir $(\mathrm{KBr}): 1735\left(\mathrm{CO}_{2} \mathrm{R}\right)$ and $1690(\mathrm{PhC}=0) \mathrm{cm}^{-1}$.

Preparation of Impure Ketoesters 19 and 20

A suspension of $3 \mathrm{~g}$ of polymer 17 was cleaved with $\mathrm{K}_{2} \mathrm{CO}_{3}$ in methanol (10) and the product was esterified with $\mathrm{CH}_{2} \mathrm{~N}_{2}$ to yield $400 \mathrm{mg}$ of a mixture of $46 \%$ methyl 10-oxo-10-phenyldecanoate (19) (18) and 54\% dimethyl sebacate (14) which was not further purified. Although the products 19 and 14 were inseparable by preparative tlc, the ratio of 19 to 14 could be readily determined from the nmr spectrum of the mixture using the nmr spectrum of pure 14 as a comparison. The ir (neat) spectrum of the mixture exhibited a strong absorbance at $1750-1730\left(\mathrm{CO}_{2} \mathrm{R}\right)$ $1695(\mathrm{PhCO}), 1600$ and 1590 (phenyl), and $1100(\mathrm{C}-\mathrm{O}) \mathrm{cm}^{-1}$ $\mathrm{nmr} 8: 8.0(\mathrm{~m}$, ortho aromatic $2 H), 7.4(\mathrm{~m}$, aromatic $3 H), 3.7(\mathrm{~s}$ $\left.\mathrm{OCH}_{3}\right), 3.0\left(\mathrm{t}, J=7 \mathrm{~Hz}, \mathrm{CH}_{2} \mathrm{COPh}\right), 2.32(\mathrm{t}, J=7.5 \mathrm{~Hz}$, $\left.\mathrm{CH}_{2} \mathrm{CO}_{2}\right)$, and $1.1-1.9\left(\mathrm{~m}, \mathrm{CH}_{2}\right)$.

Similarly 18 yielded a mixture containing $54 \%$ methyl 9-oxo9-phenylnonanoate (20) and $46 \%$ dimethyl azeloate (21), ir (neat) $1750-1730\left(\mathrm{CO}_{2} \mathrm{R}\right), 1695$ (PhCO), 1600 and 1590 (phenyl) $\mathrm{cm}^{-1}$ $\mathrm{nmr} \delta: 7.9(\mathrm{~m}$, ortho aromatic $2 H), 7.4(\mathrm{~m}$, aromatic $3 H), 3.7(\mathrm{~s}$ $\left.\mathrm{OCH}_{3}\right), 2.98\left(\mathrm{t}, J=7 \mathrm{~Hz}, \mathrm{CH}_{2} \mathrm{COPh}\right), 2.31(\mathrm{t}, J=7 \mathrm{~Hz}$, $\left.\mathrm{CH}_{2} \mathrm{CO}_{2}\right)$, and $1.2-1.8\left(\mathrm{~m}, \mathrm{CH}_{2}\right)$.

\section{Acknowledgement}

We are grateful for the financial assistance of the Natural Sciences and Engineering Research Council of Canada for support of this research.

1. P. M. Worster, C. R. McArthur, and C. C. Leznoff. Angew. Chem. Int. Ed. Engl. 18, 221 (1979)
2. P. I. Svirskaya and C. C. Leznoff. J. Chem. Eng. Data, 24, 152 (1979).

3. C. C. Leznoff and P. I. Svirskaya. Angew. Chem. Int. Ed. Engl. 17, 947 (1978).

4. D. M. Dixit and C. C. Leznoff. Isr. J. Chem. 17, 248 (1978).

5. W. S. Johnson, J. W. Peterson, and W. P. Schneider. J. Am. Chem. Soc. 69, 74 (1947).

6. T. Veda, S. Kato, S. Toyoshima, and J. Takada. Chem. Abstr. 59, 2726b (1963).

7. F. G. BadDar, L. S. El-Assal, and A. Habashi. J. Chem. Soc. 456(1955).

8. C. C. LEZNOFF. Acc. Chem. Res. 11, 327 (1978).

9. C. C. LeZnoFF and J. M. GoldwASSER. Tetrahedron Lett. 1875 (1977).

10. J. M. Golowasser and C. C. Leznoff. Can. J. Chem. 56, 1562 (1978).

11. G. Cahiez, A. Masuda, D. Bernard, and J. F. NorMANT. Tetrahedron Lett. 3155 (1976); G. CAHIEZ, D. BERNARD, and J. F. Normant. Synthesis, 130(1977).

12. G. Cahiez and J. F. NoRmant. Tetrahedron Lett. 3383 (1977).

13. G. Cauquil, J. Rouzard, R. E. Lyle, H. L. Fielding, and G. G. LyLE. Bull. Chim. Soc. Fr. 513 (1955).

14. J. I. Crowley and H. Rapoport. Acc. Chem. Res. 9, 135 (1976).

15. K. M. Patel, H. J. Pownall, J. D. Morrisett, and J. T. SPARROW. Tetrahedron Lett. 4015 (1976).

16. G. M. Whitesides, W. F. Fisher JR., J. SAN Filippo JR., R. W. BAshe, and H. O. House. J. Am. Chem. Soc. 91, 4871 (1969).

17. J. M. STEwart and J. D. Young. Solid phase peptide synthesis. W. H. Freeman Ltd., San Francisco, CA. 1969. pp. 27-28.

18. M. D. Soffer, N. S. Strauss, M. D. Trail, and K. W. Sherk. J. Am. Chem. Soc. 69, 1684 (1947). 